\title{
COVID-19 Vaccination acceptance in the canton of Geneva: A Cross-Sectional Population-Based Study
}

Ania Wisniak ${ }^{1,2}$, Hélène Baysson¹, Nick Pullen¹, Mayssam Nehme ${ }^{3}$, Francesco Pennacchio ${ }^{1}$, María-

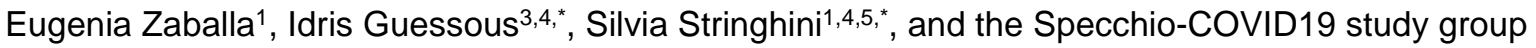

\section{Specchio-COVID19 study group}

Isabelle Arm-Vernez, Andrew S Azman, Fatim Ba, Oumar Aly Ba, Delphine Bachmann, Jean-François Balavoine, Michael Balavoine, Hélène Baysson, Lison Beigbeder, Julie Berthelot, Patrick Bleich, Gaëlle Bryand, François Chappuis, Prune Collombet, Delphine Courvoisier, Alain Cudet, Carlos de Mestral Vargas, Paola D'Ippolito, Richard Dubos, Roxane Dumont, Isabella Eckerle, Nacira El Merjani, Antoine Flahault, Natalie Francioli, Marion Frangville, Idris Guessous, Séverine Harnal, Samia Hurst, Laurent Kaiser, Omar Kherad, Julien Lamour, Pierre Lescuyer, François Lhuissier, Fanny-Blanche Lombard, Andrea Jutta Loizeau, Elsa Lorthe, Chantal Martinez, Lucie Ménard, Lakshmi Menon, Ludovic Metral-Boffod, Benjamin Meyer, Alexandre Moulin, Mayssam Nehme, Natacha Noël, Francesco Pennacchio, Javier Perez-Saez, Giovanni Piumatti, Didier Pittet, Jane Portier, Klara M Posfay-Barbe, Géraldine Poulain, Caroline Pugin, Nick Pullen, Zo Francia Randrianandrasana, Aude Richard, Viviane Richard, Frederic Rinaldi, Jessica Rizzo, Khadija Samir, Claire Semaani, Silvia Stringhini, Stéphanie Testini, Guillemette Violot, Nicolas Vuilleumier, Ania Wisniak, María-Eugenia Zaballa

1. Unit of Population Epidemiology, Division of Primary Care Medicine, Geneva University Hospitals, Geneva, Switzerland

2. Institute of Global Health, Faculty of Medicine, University of Geneva, Geneva, Switzerland

3. Division and Department of Primary Care Medicine, Geneva University Hospitals, Geneva, Switzerland

4. University Center for General Medicine and Public Health, University of Lausanne, Lausanne, Switzerland

5. Department of Health and Community Medicine, Faculty of Medicine, University of Geneva, Geneva, Switzerland

*These authors contributed equally to this work.

\section{Corresponding author:}

Ania Wisniak

Unit of Population Epidemiology

Geneva University Hospitals

Ania.wisniak@hcuge.ch

NOTE: This preprint reports new research that has not been certified by peer review and should not be used to guide clinical practice. 
medRxiv preprint doi: https://doi.org/10.1101/2021.07.05.21260024; this version posted July 6,2021 . The copyright holder for this preprint (which was not certified by peer review) is the author/funder, who has granted medRxiv a license to display the preprint in perpetuity.

It is made available under a CC-BY-NC-ND 4.0 International license.

\section{Word count}

Abstract: 388

Main text: 4'612 
medRxiv preprint doi: https://doi.org/10.1101/2021.07.05.21260024; this version posted July 6, 2021. The copyright holder for this preprint (which was not certified by peer review) is the author/funder, who has granted medRxiv a license to display the preprint in perpetuity.

It is made available under a CC-BY-NC-ND 4.0 International license .

\section{Abstract}

Objective This study aimed to assess acceptance of COVID-19 vaccination as well as its sociodemographic and clinical determinants in a general population sample three months after the launch of the vaccination program in Switzerland.

Methods In March 2021, an online questionnaire on vaccination acceptance was proposed to adults included in a longitudinal cohort study of previous population-based serosurveys carried out in the canton of Geneva. Questions were asked about COVID-19 vaccination acceptance, reasons of acceptance or refusal, and attitudes about vaccination in general. Data on demographic (age, sex, education, income, professional status, living conditions) and health-related characteristics (having a chronic disease, COVID-19 diagnosis, smoking status) were assessed at inclusion in the cohort (December 2020).

Results Overall, 4'067 participants (completion rate of $77.4 \%$ ) responded to the survey between March 17 and April 1, 2021. The mean age of respondents was 53.3 years and $56.0 \%$ were women. Most had completed tertiary education (64.7\%) and over $60 \%$ were currently professionally active. At the time of the survey, $17.2 \%$ of respondents had already been vaccinated with at least one dose or had made an appointment to get vaccinated, and an additional $58.5 \%$ intended or rather intended to get vaccinated. The overall acceptance of COVID-19 vaccination was $75.7 \%$, with a higher acceptance among men compared to women, older adults compared to younger adults, high-income individuals compared to those with a low income, participants living in urban and semi-urban areas compared to rural, and retirees and students compared to employed individuals. Acceptance was lower among individuals having completed apprenticeships and secondary education compared to those with tertiary education. The most common reasons reported by participants intending to get vaccinated were the desire to 'get back to normal', to protect themselves, their community and/or society, and their relatives or friends against the risk of infection by SARS-CoV-2, as well as the desire to travel. Less than half $(45.6 \%)$ of participants having children were willing or rather willing to have their children vaccinated against COVID-19 if it were recommended by public health authorities.

Conclusion Although our study found a $75.7 \%$ acceptance of COVID-19 vaccination, there were noticeable socio-demographic disparities in vaccination acceptance. These data will be useful for public health measures targeting hesitant populations when developing health communication strategies. These results will be updated over time with a new release of the survey in autumn 2021.

Keywords: COVID19, vaccine, COVID-19 vaccination, vaccination hesitancy, acceptability 
medRxiv preprint doi: https://doi.org/10.1101/2021.07.05.21260024; this version posted July 6,2021 . The copyright holder for this preprint (which was not certified by peer review) is the author/funder, who has granted medRxiv a license to display the preprint in perpetuity. It is made available under a CC-BY-NC-ND 4.0 International license.

\section{Introduction}

In response to the COVID-19 pandemic, unprecedented global efforts have enabled the development of several safe and effective vaccines only one year after the first COVID-19 case was diagnosed in Wuhan, China. Worldwide, the first COVID-19 vaccines tested in phase 3 trials were commercialized at the beginning of December 2020, with the messenger RNA-based Comirnaty ${ }^{\circledR}$ vaccine of Pfizer/BioNTech ${ }^{1}$ being the first authorized in the United Kingdom on December 3, 2020. In addition to manufacturing and logistical challenges, vaccination campaigns worldwide have been challenged by diffuse distrust of the population regarding the safety and efficacy of these novel vaccines. ${ }^{2-6}$

Vaccine hesitancy fueled by misinformation campaigns has often been a threat to sufficient vaccine coverage over past decades, sometimes leading to resurgence of vaccine-preventable diseases. ${ }^{7-9}$ This has led the World Health Organization to recognize vaccine hesitancy as a major threat to global health in 2019. ${ }^{10}$ International efforts to urgently deliver a safe and effective vaccine against COVID-19 have been faced with a growing anti-vaccination movement amplified by social media since the early phases of the pandemic, with the potential to negatively impact vaccination uptake in populations exposed to these campaigns. ${ }^{2,5,11-13}$

By December 23, 2020, the date of the launch of COVID-19 vaccination, Switzerland had reported 4'896 confirmed cases/100'000 inhabitants and 6'406 deaths since the beginning of the pandemic. ${ }^{14}$ In addition to the direct health consequences of COVID-19, social distancing measures and closure of nonessential services have led to negative social, psychological and economic consequences. In the canton of Geneva, a population-based serological survey has shown that by the end of December 2020, 21.1\% of the canton's population had been infected with SARS-CoV-2 since the start of the pandemic ${ }^{15}$, suggesting a relatively slow rise of population immunity if social distancing measures preventing the collapse of health care systems were to be pursued. At the time of our survey, during the last two weeks of March 2021, two messenger RNA-based vaccines were available in Switzerland - the Comirnaty® (BNT162b2) vaccine of Pfizer/BioNTech ${ }^{1}$ and the COVID-19 vaccine (mRNA-1273) of Moderna ${ }^{16}$ vaccines. At that time in the canton of Geneva, vaccination priority was given to individuals aged 65 years and older, individuals deemed 'particularly vulnerable to COVID-19', as well as health workers in close contact with at-risk patients. ${ }^{17}$

Reaching sufficient coverage, however, is in large part dependent on the population's willingness to get vaccinated. A national survey conducted in Switzerland shortly before the arrival of the first vaccines on the market revealed that only $56 \%$ of respondents were likely to accept vaccination against COVID-19, with a lack of trust in the security of the vaccines being the main reason for refusal. ${ }^{18}$ Furthermore, previous studies have shown that vaccine hesitancy was associated to socio-demographic factors such as younger age, female gender, lower income and lower education. 2,19,20 In order to address vaccine hesitancy in a comprehensive way and deliver targeted interventions, reasons for accepting or refusing vaccination, as well as associated socio-economic factors should be explored in a regional context, as results found in other countries cannot be extended to all populations, due to cultural, political and organizational factors influencing vaccination acceptance. In addition, taking into account people's 
medRxiv preprint doi: https://doi.org/10.1101/2021.07.05.21260024; this version posted July 6, 2021. The copyright holder for this preprint (which was not certified by peer review) is the author/funder, who has granted medRxiv a license to display the preprint in perpetuity.

It is made available under a CC-BY-NC-ND 4.0 International license .

positive or negative emotions about vaccination is essential to developing effective communication campaigns. ${ }^{21}$

The aim of our study was 1) to assess the population's willingness to get vaccinated against COVID-19 three months after the launch of the vaccination program in Geneva, Switzerland, 2) to explore individuals' attitudes towards COVID-19 vaccination and their reasons for accepting or declining the vaccination, and 3) to describe associations between socio-economic or health-related factors and vaccine hesitancy.

\section{Methods}

\section{Study design, setting and sample}

This population-based cross-sectional study was embedded in a longitudinal digital cohort study called Specchio-COVID19, which was launched in December 2020 to follow up over time participants of serosurveys conducted in the canton of Geneva. ${ }^{22}$ Serosurvey participants were randomly selected from the general population at two time points: 1) between April and June 2020, participants were enrolled from a previous general health survey representative of the population of the Canton of Geneva aged between 20 and 75 years old ${ }^{23}$, and 2) between November and December 2020, participants were randomly selected from registries of the Canton of Geneva stratified by age and sex ${ }^{15}$.

After a baseline serologic test, participants were invited to join the Specchio-COVID19 study, which consists in a long-term follow-up by collecting data through regular on-line questionnaires and serological follow-up. Upon registration, an initial questionnaire assessed socio-demographic and lifestyle characteristics and general health-related data. Self-reported SARS-CoV-2 infections and risk perception of COVID-19 are updated through monthly questionnaires. The questionnaire designed for this study was sent out to participants on March 17, 2021, with a reminder sent two weeks later.

\section{Data collected in the COVID-19 vaccination questionnaire}

The "vaccination" questionnaire was based on a literature review and was validated by public health experts and physicians. Part of the content was developed in the framework of the Corona Immunitas research program, a national program aiming to coordinate regional SARS-CoV-2 seroprevalence studies across Switzerland. ${ }^{24}$ The questionnaire measured COVID-19 vaccination status, intention to get vaccinated, reasons to get vaccinated, reasons for refusing vaccination, vaccination-related beliefs (e.g., perceived efficacy, perceived safety, preference for natural immunity), perceived utility of COVID19 vaccination, willingness to vaccinate one's children against COVID-19, and attitude towards vaccination in general. The questionnaire also included three questions from a French study on vaccination hesitancy ${ }^{25}$ adapted from the World Health Organization's Strategic Advisory Group of Experts (SAGE) definition of vaccine hesitancy ${ }^{26}$, general attitudes regarding vaccination, and trust in public health authorities, pharmaceutical companies, scientists and researchers. These questions are described in more detail in the supplementary materials. Two questions were additionally asked on the 
medRxiv preprint doi: https://doi.org/10.1101/2021.07.05.21260024; this version posted July 6,2021 . The copyright holder for this preprint (which was not certified by peer review) is the author/funder, who has granted medRxiv a license to display the preprint in perpetuity.

It is made available under a CC-BY-NC-ND 4.0 International license .

perception of immunity certificates for COVID-19, for which analyses were conducted and described in a separate paper submitted to the same journal.

Vaccination intention was defined as the combined answer to the following two questions: "Were you already vaccinated against COVID-19? (Yes, No, Scheduled appointment)" and "Do you intend to get vaccinated once you will be eligible for vaccination against COVID-19? (Yes, rather yes, rather no, no, does not know)". Answers "Yes", "Scheduled appointment" to the first question and answers "Yes" and "Rather yes" to the second question were later combined as willingness to get vaccinated. Answers "No" and "Rather no" to the second question were defined as no willingness to get vaccinated.

We constructed the variable 'Vaccine hesitancy' (hesitant/not hesitant) based on the SAGE definition, categorizing as 'hesitant' participants who had at some point refused vaccination and/or delayed vaccination and/or accepted vaccination despite doubts on its effectiveness. Those who answered 'no' to all three questions were considered 'not vaccine hesitant'.

Previous SARS-CoV-2 infection was defined as being either SARS-CoV-2 seropositive or having selfreported a positive PCR or antigenic test for SARS-CoV-2 in one of the monthly surveys.

Education was categorized as follows: 1) compulsory education or no formal education, 2) apprenticeships, 3) secondary school and specialized schools, and 4) tertiary education including universities, higher professional education, and doctorates.

Income was categorized as 'low' (below the first quartile of the general population of the canton of Geneva), 'medium' (between the first and third quartiles) or 'high' (above the third quartile) taking into account self-reported household income from the baseline questionnaire, as well as household composition (living alone with or without children, in a relationship with or without children, or in a shared apartment with other adults), and according to household income statistics for the same household composition categories within the canton of Geneva. ${ }^{27}$

\section{Statistical analysis}

Descriptive analyses included percentages with comparisons using chi-square tests for categorical variables. P-values were considered significant at $p<0.05$.

Logistic regression analyses were conducted to assess the associations of demographic and healthrelated factors with COVID-19 vaccination intention. Simple univariate logistic models were run for all of the following variables individually: sex, age, education, household income, residential area, employment status, living conditions, having a chronic disease, smoking status, previous SARS-CoV-2 infection, perception of COVID-19 severity and contagiousness, and vaccine hesitancy. For each variable we also ran multivariable logistic regressions adjusting for age, sex, education and income. The intersex category as well as the "non available" (NA) categories for all variables were excluded from the logistical regression analysis due to low counts. Odds ratios and confidence intervals were calculated through exponentiation of estimated coefficients. Statistical significance was taken at the level of $p<0.05$ 
medRxiv preprint doi: https://doi.org/10.1101/2021.07.05.21260024; this version posted July 6,2021 . The copyright holder for this preprint (which was not certified by peer review) is the author/funder, who has granted medRxiv a license to display the preprint in perpetuity. It is made available under a CC-BY-NC-ND 4.0 International license .

a priori. All analyses were conducted using R 4.0.3 (R Foundation for Statistical Computing, Vienna, Austria).

\section{Ethical Considerations}

All participants of the Specchio-COVID19 digital platform provided informed and written consent upon enrolment in the study. Ethical approval for the study was obtained from the Cantonal Research Ethics Commission of Geneva, Switzerland (project number 2020-00881).

\section{Results}

\section{Descriptive characteristics of the sample}

From the original 8'904 adult serosurvey participants invited to be followed-up longitudinally, 5'282 enrolled in the digital cohort (participation rate 59.3\%, not taking into account unreachable participants due to false email addresses), among which 30 withdrew their participation prior to the vaccination survey. Overall, 4'067 participants (completion rate of $77.4 \%$ ) responded to the vaccination survey between March 17 and April 1, 2021 (the study flow chart is presented in supplementary materials, figure S1). The mean age of participants was 53.3 years ( $+/-14.4$ years standard deviation) and $56.0 \%$ were women. Most had completed a tertiary education $\left(n=2{ }^{\prime} 631 ; 64.7 \%\right)$ and over $60 \%$ were currently professionally active (as an independent or an employee). Overall characteristics are presented in supplementary materials (Table S1). In comparison with the general population in the Canton of Geneva, our sample had older participants (27.9\% individuals aged $18-34$ years in Geneva vs. $10.4 \%$ in our sample) and a higher education level (64.9\% higher education in our sample vs. $39.9 \%$ in the Geneva population) (Supplementary materials, Table S2).

Compared to non-respondents, participants responding to the vaccination survey were older (mean age $53.3+/-14.4$ years vs. $43.8+/-14.4$ years), more highly educated $(64.7 \%$ vs. $63.2 \%$ had tertiary education, $3.9 \%$ vs. $6.8 \%$ had no formal education, $p<0.001)$, had a higher income $(12.9 \%$ vs. $16.3 \%$ had low income, $64.8 \%$ vs. $55.9 \%$ middle or high income, $p<0.001)$, were more frequently retired $(25.9 \%$ vs. $9.8 \%$ ) and less frequently students ( $4 \%$ vs. $12 \%, p<0.001)$ and were less frequently current smokers $(14.9 \%$ vs. $19.2 \%, p<0.001)$. Socio-demographic and health-related characteristics of survey respondents compared to non-respondents are presented in supplementary materials (Table S1).

\section{Vaccination status and intention}

At the time of the survey, $17.2 \%$ of respondents had already been vaccinated with at least one dose or had made an appointment to get vaccinated. Moreover, 58.5\% of participants intended or rather intended to get vaccinated, while only $13.8 \%$ did not or rather did not intend to get vaccinated, and $10.4 \%$ did not know if they intended to get vaccinated (Figure 1). 
medRxiv preprint doi: https://doi.org/10.1101/2021.07.05.21260024; this version posted July 6,2021 . The copyright holder for this preprint (which was not certified by peer review) is the author/funder, who has granted medRxiv a license to display the preprint in perpetuity.

It is made available under a CC-BY-NC-ND 4.0 International license .

\section{General perception of COVID-19 vaccination usefulness}

A large majority (92.3\%) agreed or rather agreed that COVID-19 vaccination was an important step to end the pandemic. When stratified by vaccination intention, those willing to or already vaccinated agreed the most with this statement $(99.4 \%)$, although even those not intending to get vaccinated acknowledged the importance of vaccination at a majority (57.1\%) (Figure $2 \mathrm{~A}$ ). Similarly, a majority of participants $(78.5 \%)$ considered that vaccinated individuals should continue following preventive measures such as wearing face masks. Individuals willing to or already vaccinated were more likely to agree with this statement $(81.9 \%)$ when compared to those not willing to get vaccinated (64.6\%) (Figure 2B).

\section{Willingness to vaccinate children}

Participants with children under the age of $18(N=1$ '339) were asked whether they would be willing to have their children vaccinated against COVID-19 if it was recommended by public health authorities. Less than half $(45.6 \%)$ agreed or rather agreed, and approximately one quarter did not know (Figure $2 \mathrm{C})$. When stratified by vaccination intention for oneself, those intending or rather intending to get vaccinated were mainly willing to have their children vaccinated $(63.6 \%)$, while among participants not intending to get vaccinated or not yet sure, they were only $5.6 \%$ and $6.5 \%$, respectively. Importantly, a high proportion of parents intending to get vaccinated $(25.3 \%)$ and not yet sure about their intention $(47.8 \%)$ were still undecided regarding vaccination of their children against COVID-19. These results were also stratified by parents' education level and children's age (the youngest child's age was considered for parents with more than one child), showing the highest willingness rate for children's vaccination among the most $(50.5 \%)$ and the least (46.2\%) educated, and an apparent gradient in willingness with increasing children's age from 6 years old (between $38.6 \%$ for children aged 6 to 10 , to $55.9 \%$ for children aged 16 to 18 ). These results are detailed in supplementary materials (Table S3).

\section{Reasons for Covid-19 vaccine acceptance and refusal}

Main reasons for intending to get vaccinated and for refusing vaccination are listed in Table 1. The most common reasons reported by participants were the desire to 'get back to normal' (78.4\%), and to protect themselves $(75.4 \%)$, as well as their community and/or society $(70.1 \%)$ against the risk of infection by SARS-CoV-2.

Among those not intending to get vaccinated, the most common reason selected was the 'preference to wait' by $53.9 \%$ of participants. Other common reasons for refusing vaccination were not being afraid of being infected by SARS-CoV-2 (27.6\%), the preference for other preventive measures $(27.4 \%)$, worry or fear of getting vaccinated (24.4\%), feeling protected by a previous infection with SARS-CoV-2 (23.7\%) and believing that the vaccine does not prevent transmission of the virus $(20.8 \%)$. Overall, $13.5 \%$ of participants not intending to get vaccinated stated being against vaccines in general.

Participants who did not intend to get vaccinated against COVID-19 were additionally asked which elements would change their minds in favor of vaccination. More than half indicated that more reliable information on vaccine efficacy and scientific results showing low risk of side effects might make them more favorable towards getting vaccinated, and $33.5 \%$ reported that making vaccination mandatory in 
medRxiv preprint doi: https://doi.org/10.1101/2021.07.05.21260024; this version posted July 6,2021 . The copyright holder for this preprint (which was not certified by peer review) is the author/funder, who has granted medRxiv a license to display the preprint in perpetuity.

It is made available under a CC-BY-NC-ND 4.0 International license .

certain contexts (e.g. traveling) would have that effect. Overall, $12.3 \%$ of those not willing to get vaccinated stated that they would not change their minds.

\section{Change in vaccination intention}

Overall, in the three months preceding the questionnaire, $21.9 \%$ of all participants declared a change in intention to get vaccinated against COVID-19, with most becoming more favorable towards vaccination (19.8\%) (Table 2a). Of note, those participants who declared still being ambivalent towards vaccination ('do not know') had mostly changed their minds in favor of vaccination ( $20.5 \%$ vs. $5.2 \%)$, while those who did not intend to get vaccinated became more or less in favor of vaccination in more equal proportions (5.9\% vs. $6.8 \%$, respectively).

Among the participants who changed their mind in the past three months, those more in favor of vaccination indicated the change in the sanitary situation $(60.9 \%)$, information shared by public health authorities (49.1\%) and new measures in place (e.g. regarding travel) $(42.7 \%)$ as main reasons for this change. On the other hand, participants who became less in favor of vaccination did so mainly due to the information shared in the media $(51.2 \%)$, by public health authorities $(41.9 \%)$, as well as a change in the sanitary situation (33.7\%) (Table $2 b$ ).

\section{Drivers of vaccination intention}

Vaccination intention differed by demographic characteristics, with men compared to women (adjusted odds ratio $(\mathrm{aOR}) 1.37,95 \% \mathrm{Cl} 1.12-1.67)$ and older adults compared to adults aged 18 to 34 years (aOR 1.86, $95 \% \mathrm{Cl} 1.36-2.55$, and aOR 5.55, 95\% Cl 3.79-8.19, for 50-64 and 65 years and older, respectively) more likely to accept COVID-19 vaccination (Table 3).

Regarding socio-economic characteristics, people who had done apprenticeships (aOR $0.47,95 \% \mathrm{Cl}$ $0.37-0.61$ ) or had a secondary education (aOR $0.67,95 \% \mathrm{Cl} 0.51-0.89$ ) were less likely to intend to get vaccinated than people having completed tertiary education. The odds did not differ significantly for individuals with compulsory or no formal education. Further, the odds of vaccination willingness were higher in individuals with higher income compared to low income (OR 2.56, 95\% Cl 1.73-3.83), in retirees (aOR 1.68, 95\% Cl 1-2.89) and students (aOR 2.16, 95\% Cl 1.19-4.09) compared to individuals in the workforce, as well as in participants residing in semi-urban (aOR 1.59, 95\% Cl 1.22-2.07) and urban (aOR 1.95, 95\% $\mathrm{Cl} 1.51-2.51$ ) areas compared to rural areas.

Vaccination intention also differed by clinical characteristics, with people without any chronic disease less likely to intend to get vaccinated than those having reported at least one chronic disease (aOR 0.6, $95 \% \mathrm{Cl}$ 0.47-0.77), as well as individuals who had been infected by SARS-CoV-2 compared to those who had never had COVID-19 (aOR 0.61, 95\% Cl 0.49-0.76).

People who had a lower perception of severity and contagiousness of COVID-19 were less likely to accept vaccination than those with a higher risk perception, with an increasing trend of vaccination intention from those grading COVID-19 as 'not at all severe' (aOR $0.01,95 \% \mathrm{Cl} 0-0.04$ ) to 'very severe' (aOR $0.29,95 \% \mathrm{Cl} 0.05-0.99$ ) compared to 'extremely severe', and from 'not at all contagious' (aOR $0.03,95 \% \mathrm{Cl} 0-0.21$ ) to 'very contagious' (aOR $0.25,95 \% \mathrm{Cl} 0.11-0.46$ ) compared to 'extremely 
medRxiv preprint doi: https://doi.org/10.1101/2021.07.05.21260024; this version posted July 6, 2021. The copyright holder for this preprint (which was not certified by peer review) is the author/funder, who has granted medRxiv a license to display the preprint in perpetuity.

It is made available under a CC-BY-NC-ND 4.0 International license .

contagious'. Finally, vaccine hesitancy was negatively associated with vaccination intention (aOR 0.44 , $95 \% \mathrm{Cl}$ 0.36-0.53), although $33.4 \%$ of those intending to get vaccinated against COVID-19 were categorized as 'vaccine hesitant', while almost half of those not intending to get vaccinated were not generally vaccine hesitant.

\section{Discussion}

This study carried out in the canton of Geneva showed an overall COVID-19 vaccination acceptance of $75.7 \%$, including those already vaccinated, and those who intended or rather intended to get vaccinated once eligible. This rate of vaccine acceptance was consistent with previous studies carried out in other developed countries, such as the United states $(67 \%)^{28}$, Japan $(62.1 \%)^{29}$, Ireland $(65 \%)$ and the United Kingdom (between $69 \%$ to $86 \%$ across studies) ${ }^{30,31}$. However, the range of vaccine acceptance has been seen to vary widely between countries, from $29.4 \%$ reported in a study in Jordan, Kuwait and Saudi Arabia, to $86 \%$ in in the United Kingdom. ${ }^{31}$

The most frequently provided reasons for intending to get vaccinated were to protect oneself, to protect the community and to return to a normal life. These reasons were similar to those obtained in other countries. ${ }^{31}$ Interestingly, $80 \%$ of those willing to get vaccinated were of the opinion that vaccinated people should continue to follow preventive measures against viral spread. This may reflect a generally higher commitment of these participants to respecting public authority recommendations, which imposed the same preventive measures for vaccinated and non-vaccinated individuals alike at the time of the survey.

In our study, vaccination intentions were different depending on socio-demographic factors. Our results showed that men were more willing to get vaccinated than women. This is in line with previous studies on vaccination acceptance. ${ }^{31}$ Indeed, women have been reported to adopt more negative opinions about vaccination, while men have been reported to perceive a higher risk of the disease and to be less easily influenced by rumors surrounding COVID-19. ${ }^{31}$ Only one study conducted in the United States reported a lower acceptance of COVID-19 vaccination in men compared to women. ${ }^{32}$

Consistent with previous findings, this study found that older individuals were more willing to get vaccinated against COVID-19 than younger individuals. ${ }^{31}$ This could be attributed to the fact that older individuals are at increased risk of mortality and of severe forms of the disease, and had access to vaccination at the time of the survey. However, this finding could evolve rapidly over time as, since the time of this survey, COVID-19 vaccination has now been made available to all individuals aged over 12 years in Switzerland.

In addition, our study showed that high education level, high income status, as well as having a chronic disease were associated with higher vaccination acceptance, which is in line with previously published studies. ${ }^{31}$ While residing in urban or semi-urban areas was associated with vaccination acceptance in our study, other studies conducted in different settings showed conflicting results regarding residential area. ${ }^{31}$ Although targeted communication directed at clinically vulnerable populations during the 
medRxiv preprint doi: https://doi.org/10.1101/2021.07.05.21260024; this version posted July 6, 2021. The copyright holder for this preprint (which was not certified by peer review) is the author/funder, who has granted medRxiv a license to display the preprint in perpetuity. It is made available under a CC-BY-NC-ND 4.0 International license .

vaccination campaign seems to have been successful, with increased vaccination acceptance among participants with a chronic disease, our results suggest that tailored communication strategies should also focus on socially vulnerable populations. ${ }^{33}$

Furthermore, participants who had already been infected with SARS-CoV-2 (assessed either by a serologic test or a PCR-test) were less willing to get vaccinated, even though vaccination was also recommended to previously infected individuals in Switzerland at the time of the survey. To our knowledge, this is the first survey to assess vaccination acceptance in association with serological status. Being aware of these associations may provide guidance for stakeholders and health professionals to target hesitant people and potentially adapt or better explain vaccination strategies.

While $14 \%$ of participants in the current study expressed unwillingness to get vaccinated, $10 \%$ of participants remained undecided regarding their vaccination intention. Making up almost one fourth of all participants, this combined group represents a threat for the success of vaccination campaigns against COVID-19 and the achievement of a high immunization coverage. The main reasons for participants' refusal of vaccination were concerns about safety and efficacy, and a large proportion of those not intending to get vaccinated reported preferring to wait to have more data about potential sideeffects, including in the long term. Previous studies carried out worldwide have also identified doubts about the vaccine's efficacy and safety among the main reasons for vaccine hesitancy. ${ }^{31,34}$ High media coverage of the vaccination campaign and increased use of social networks may have further fueled controversies such as the potential risk of thromboembolic events following vaccination, with a heavy impact on vaccination acceptance. ${ }^{35}$

Our results show that, at the time of the survey, less than half of participants with children were willing to have their children vaccinated against COVID-19 if it were recommended by public health authorities. This is generally in line with results from other countries ${ }^{36-39}$, which have shown parental acceptance varying between $36.3 \%$ in Turkey ${ }^{38}$ to $60.4 \%$ in Canada ${ }^{36}$. Consistent with other studies, child vaccination intention varied according to children's age ${ }^{35}$, with acceptance increasing with the child's age from 6 years old in our study, and to educational level ${ }^{36-38}$, with a higher acceptance rate among parents with a tertiary education and those with a compulsory education only. Importantly, COVID-19 vaccination was not yet authorized in children under 16 years old at the time of the survey, while it is now recommended for those aged 12 years and older in Switzerland, which may strongly impact parental acceptance. Also, willingness to vaccinate one's children may increase as more evidence is being made available regarding potential long-term sequelae of COVID-19 in children and adolescents. ${ }^{40}$

In our study, $33.4 \%$ of those intending to get vaccinated against COVID-19 or already vaccinated were categorized as generally 'vaccine hesitant', while almost half of those not intending to get vaccinated were not generally vaccine hesitant. This result suggests that COVID-19 vaccination does not seem to be perceived in the same way as other recommended vaccines. Although it is already known that urgently released vaccines are received with greater skepticism than established or well-known vaccines $^{33}$, COVID-19 vaccines may trigger even higher distrust due to their unusually rapid development. 
medRxiv preprint doi: https://doi.org/10.1101/2021.07.05.21260024; this version posted July 6, 2021. The copyright holder for this preprint (which was not certified by peer review) is the author/funder, who has granted medRxiv a license to display the preprint in perpetuity.

It is made available under a CC-BY-NC-ND 4.0 International license .

\section{Implications for public health policies}

Results from this study provide a clear insight of socio-demographic subgroups that remain hesitant or refuse COVID-19 vaccination. Interestingly, more than half of those not intending to get vaccinated against COVID-19 agreed that the vaccine was an important step to end the pandemic. As suggested by our results, these individuals may be more likely to change their minds if reassured about the security of vaccines. Although there is sufficient clinical evidence about the efficacy, safety and side effects of authorized COVID-19 vaccines, this evidence needs to be better communicated and disseminated among the general population in order to alleviate common concerns.

Further, our results showed that information shared by public health authorities could lead to change in intention both in favor and against vaccination in similar proportions. These results highlight the importance of improving communication at a population level. Fortunately, empirical data showed that building vaccination trust among hesitant individuals is possible with effective communication strategies, which could be based on social marketing campaigns at the population level 34,41 or on targeted campaigns tailored to specific subgroups. ${ }^{42}$ Accordingly, public health organizations, health care professionals and digital platforms should collaborate to guarantee the availability of accessible and accurate information.

\section{Strengths and limitations}

The main strengths of this study are is its large sample size with all adult ages represented, as well as the availability of data on sociodemographic (age, sex, education level, income) and health-related characteristics (serologic status, chronic diseases, smoking status) which allowed stratification of COVID-19 vaccination acceptance according to these factors. Very little research has been conducted on the drivers of COVID-19 vaccine acceptance now that vaccination is available to the general population. Indeed, most previous studies carried out globally were conducted in periods when COVID19 vaccines were not available or accessible only to certain groups, such as healthcare workers or key workers. ${ }^{43,44}$ It is also of outright importance to investigate the factors influencing perception of COVID19 vaccination at the local level, as vaccination hesitancy may be widely influenced by regional and cultural factors.

Several limitations of our study should be acknowledged. Although participation rate in this study was high, generalization of the results presented here requires caution as our sample is not completely representative of the general population of the canton of Geneva. While we mitigated this by collecting and adjusting our results for important socio-demographic characteristics, a selection bias remains. Participation required French literacy, internet access and digital literacy, potentially excluding part of the general population. Respondents to the survey were older than the general population in Geneva. As older individuals are more vulnerable to COVID-19, this may have resulted in an overestimate of the overall acceptance of COVID-19 vaccination.

Furthermore, the cross-sectional survey design represents a snapshot in time, rather than the evolving landscape of the public's attitudes about COVID-19 vaccination. Vaccine hesitancy, perceptions, and 
medRxiv preprint doi: https://doi.org/10.1101/2021.07.05.21260024; this version posted July 6, 2021. The copyright holder for this preprint (which was not certified by peer review) is the author/funder, who has granted medRxiv a license to display the preprint in perpetuity.

It is made available under a CC-BY-NC-ND 4.0 International license .

concerns may change over time. Our results should be interpreted considering this specific time period when vaccination was only accessible to people aged above 65 years or to people with chronic diseases at risk of severe forms of COVID-19. Our survey will be repeated over time to provide updated information and adjust public health messages as appropriate. Furthermore, other factors potentially impacting vaccination hesitancy were not investigated, such as origin, religious or political views, which are likely to influence individual perceptions and behavior. Another aspect that could be worth exploring is the 'imitation effect' or the influence of one's social network on vaccination perception.

Finally, we need to keep in mind that acceptance or intent does not automatically translate into actual behavior. Despite a high vaccination rate to date, with more than half of the population of the canton of Geneva vaccinated with at least one dose ${ }^{45}$, there is a risk that the vaccination rate could reach a plateau, especially in the context of summer holidays and the slowdown of the pandemic in past months. Once vaccination against COVID-19 of all willing individuals will have been achieved, increased efforts will have to be put in place to reach the more reluctant part of the population and those with fewer access to information about the vaccination campaign.

\section{Conclusion}

Our study found that $75.7 \%$ of our sample from the canton of Geneva would accept COVID-19 vaccination or was already vaccinated at the time of the survey. However, socio-demographic variations in rates of acceptance were evidenced that need to be carefully addressed. Policy makers and stakeholders should provide reassuring messages about side effects and effectiveness of the vaccination. This cross-sectional survey will be repeated approximately every six months in order to follow the level of COVID-19 vaccination acceptance over time, which may be influenced by new incentives such as the establishment of a COVID-19 vaccine certificate or new policy for traveling, as well as the pandemic progression and new outbreaks. These data may help inform policy makers to develop effective and targeting communication strategies.

\section{Authors' contributions}

SS, IG and HB designed the study. HB, AW, MN and SS designed the questionnaire for the survey. $\mathrm{MZ}, \mathrm{FP}, \mathrm{HB}$ and $\mathrm{AW}$ were involved in participant recruitment and implementation of the survey. NP conducted statistical analyses of the data. AW and HB drafted the manuscript. All authors participated to analysis interpretation and approved the final manuscript.

\section{Funding}

This study was funded by the Swiss Federal Office of Public Health, the General Directorate of Health of the Department of Safety, Employment and Health of the canton of Geneva, the Private Foundation of the Geneva University Hospitals, the Swiss School of Public Health (Corona Immunitas Research Program) and the Fondation des Grangettes.

\section{Acknowledgements}


medRxiv preprint doi: https://doi.org/10.1101/2021.07.05.21260024; this version posted July 6 , 2021. The copyright holder for this preprint (which was not certified by peer review) is the author/funder, who has granted medRxiv a license to display the preprint in perpetuity.

It is made available under a CC-BY-NC-ND 4.0 International license.

We thank all the participants, without whom this study would not have been possible. 
medRxiv preprint doi: https://doi.org/10.1101/2021.07.05.21260024; this version posted July 6,2021 . The copyright holder for this preprint (which was not certified by peer review) is the author/funder, who has granted medRxiv a license to display the preprint in perpetuity.

It is made available under a CC-BY-NC-ND 4.0 International license .

\section{References}

1. Polack, F. P. et al. Safety and Efficacy of the BNT162b2 mRNA Covid-19 Vaccine. New England Journal of Medicine 383, 2603-2615 (2020).

2. Freeman, D. et al. COVID-19 vaccine hesitancy in the UK: the Oxford coronavirus explanations, attitudes, and narratives survey (Oceans) II. Psychol Med 1-15 (2020) doi:10.1017/S0033291720005188.

3. Eguia, H., Vinciarelli, F., Bosque-Prous, M., Kristensen, T. \& Saigí-Rubió, F. Spain's Hesitation at the Gates of a COVID-19 Vaccine. Vaccines (Basel) 9, (2021).

4. Afifi, T. O. et al. Older adolescents and young adults willingness to receive the COVID-19 vaccine: Implications for informing public health strategies. Vaccine (2021) doi:10.1016/j.vaccine.2021.05.026.

5. Razai, M. S., Chaudhry, U. A. R., Doerholt, K., Bauld, L. \& Majeed, A. Covid-19 vaccination hesitancy. BMJ 373, n1138 (2021).

6. Elhadi, M. et al. Knowledge, attitude, and acceptance of healthcare workers and the public regarding the COVID-19 vaccine: a cross-sectional study. BMC Public Health 21, 955 (2021).

7. Dreisinger, N. \& Lim, C. A. Resurgence of Vaccine-Preventable Disease: Ethics in the Pediatric Emergency Department. Pediatr Emerg Care 35, 651-653 (2019).

8. Feemster, K. A. \& Szipszky, C. Resurgence of measles in the United States: how did we get here? Curr Opin Pediatr 32, 139-144 (2020).

9. Papachrisanthou, M. M. \& Davis, R. L. The Resurgence of Measles, Mumps, and Pertussis. The Journal for Nurse Practitioners 15, 391-395 (2019).

10. World Health Organization. Ten threats to global health in 2019. who.int https://www.who.int/vietnam/news/feature-stories/detail/ten-threats-to-global-health-in-2019 (2019). 
medRxiv preprint doi: https://doi.org/10.1101/2021.07.05.21260024; this version posted July 6,2021 . The copyright holder for this preprint (which was not certified by peer review) is the author/funder, who has granted medRxiv a license to display the preprint in perpetuity.

It is made available under a CC-BY-NC-ND 4.0 International license .

11. Kalichman, S. C., Eaton, L. A., Earnshaw, V. A. \& Brousseau, N. Faster than warp speed: early attention to COVD-19 by anti-vaccine groups on Facebook. Journal of Public Health (2021) doi:10.1093/pubmed/fdab093.

12. Burki, T. The online anti-vaccine movement in the age of COVID-19. The Lancet Digital Health 2, e504-e505 (2020).

13. Johnson, N. F. et al. The online competition between pro- and anti-vaccination views. Nature $582,230-233(2020)$.

14. Maladie à coronavirus 2019 (COVID-19). Rapport sur la situation épidémiologique en Suisse et dans la Principauté de Liechtenstein - semaine 51 (14.12-20.12.2020). Etat 23.12.2020. https://www.bag.admin.ch/bag/en/home/krankheiten/ausbrueche-epidemienpandemien/aktuelle-ausbrueche-epidemien/novel-cov/situation-schweiz-undinternational.html\#-1680104524 (2020).

15. Stringhini, S. et al. Seroprevalence of anti-SARS-CoV-2 antibodies after the second pandemic peak. Lancet Infect Dis 21, 600-601 (2021).

16. Baden, L. R. et al. Efficacy and Safety of the mRNA-1273 SARS-CoV-2 Vaccine. New England Journal of Medicine 384, 403-416 (2021).

17. Campagne de vaccination à Genève. ge.ch https://www.ge.ch/node/23775.

18. Knotz, C. M. et al. De nombreux Suisses ne veulent pas être vaccinés contre la COVID-19 - le manque de confiance dans la sécurité des vaccins en est la cause principale - DeFacto. DeFacto Plus que des opinions https://www.defacto.expert/2020/12/22/de-nombreux-suisses-neveulent-pas-etre-vaccines-contre-la-covid-19-le-manque-de-confiance-dans-la-securite-desvaccins-en-est-la-cause-principale/?lang=fr (2020).

19. Detoc, M. et al. Intention to participate in a COVID-19 vaccine clinical trial and to get vaccinated against COVID-19 in France during the pandemic. Vaccine 38, 7002-7006 (2020).

20. Sallam, M. et al. High Rates of COVID-19 Vaccine Hesitancy and Its Association with Conspiracy Beliefs: A Study in Jordan and Kuwait among Other Arab Countries. Vaccines (Basel) 9, (2021). 
medRxiv preprint doi: https://doi.org/10.1101/2021.07.05.21260024; this version posted July 6,2021 . The copyright holder for this preprint (which was not certified by peer review) is the author/funder, who has granted medRxiv a license to display the preprint in perpetuity.

It is made available under a CC-BY-NC-ND 4.0 International license .

21. Chou, W.-Y. S. \& Budenz, A. Considering Emotion in COVID-19 Vaccine Communication:

Addressing Vaccine Hesitancy and Fostering Vaccine Confidence. Health Communication 35, 1718-1722 (2020).

22. Baysson, H. et al. The Specchio-COVID19 study cohort: a web-based prospective study of SARS-

CoV-2 serosurveys participants in the canton of Geneva (Switzerland). Submitted (2021).

23. Stringhini, S. et al. Seroprevalence of anti-SARS-CoV-2 IgG antibodies in Geneva, Switzerland (SEROCoV-POP): a population-based study. The Lancet 396, 313-319 (2020).

24. West, E. A. et al. Corona Immunitas: study protocol of a nationwide program of SARS-CoV-2 seroprevalence and seroepidemiologic studies in Switzerland. Int J Public Health 65, 1529-1548 (2020).

25. Rey, D. et al. Vaccine hesitancy in the French population in 2016 , and its association with vaccine uptake and perceived vaccine risk-benefit balance. Euro Surveill 23, (2018).

26. Schuster, M., Eskola, J. \& Duclos, P. Review of vaccine hesitancy: Rationale, remit and methods. Vaccine 33, 4157-4160 (2015).

27. Office Cantonal des Statistiques (OCSTAT). T 20.02.7.01 - Statistique cantonale du revenu et de la fortune des ménages - Quantiles du revenu annuel brut des ménages selon le type de ménage en 2015-2017 - Canton de Genève. (2020).

28. Malik, A. A., McFadden, S. M., Elharake, J. \& Omer, S. B. Determinants of COVID-19 vaccine acceptance in the US. EClinicalMedicine 26, 100495 (2020).

29. Machida, M. et al. Acceptance of a COVID-19 Vaccine in Japan during the COVID-19 Pandemic. Vaccines 9,210 (2021).

30. Murphy, J. et al. Psychological characteristics associated with COVID-19 vaccine hesitancy and resistance in Ireland and the United Kingdom. Nat Commun 12, 29 (2021).

31. Al-Jayyousi, G. F. et al. Factors Influencing Public Attitudes towards COVID-19 Vaccination: A Scoping Review Informed by the Socio-Ecological Model. Vaccines 9, 548 (2021). 
medRxiv preprint doi: https://doi.org/10.1101/2021.07.05.21260024; this version posted July 6,2021 . The copyright holder for this preprint (which was not certified by peer review) is the author/funder, who has granted medRxiv a license to display the preprint in perpetuity.

It is made available under a CC-BY-NC-ND 4.0 International license .

32. Hursh, S. R., Strickland, J. C., Schwartz, L. P. \& Reed, D. D. Quantifying the Impact of Public Perceptions on Vaccine Acceptance Using Behavioral Economics. Front Public Health 8, 608852 (2020).

33. European Centre for Disease Prevention and Control. Rapid literature review on motivating hesitant population groups in Europe to vaccinate.

https://www.ecdc.europa.eu/sites/default/files/media/en/publications/Publications/vaccination -motivating-hesistant-populations-europe-literature-review.pdf (2015).

34. Neumann-Böhme, S. et al. Once we have it, will we use it? A European survey on willingness to be vaccinated against COVID-19. Eur J Health Econ 21, 977-982 (2020).

35. Ward, J. Enquête COVIREIVAC : les français et la vaccination.

http://www.orspaca.org/sites/default/files/enquete-COVIREIVAC-rapport.pdf (2021).

36. Hetherington, E. et al. SARS-CoV-2 vaccination intentions among mothers of children aged 9 to 12 years: a survey of the All Our Families cohort. CMAJ Open 9, E548-E555 (2021).

37. Brandstetter, S. et al. Parents' intention to get vaccinated and to have their child vaccinated against COVID-19: cross-sectional analyses using data from the KUNO-Kids health study. Eur J Pediatr 1-6 (2021) doi:10.1007/s00431-021-04094-z.

38. Yılmaz, M. \& Sahin, M. K. Parents' willingness and attitudes concerning the COVID-19 vaccine: A cross-sectional study. Int J Clin Pract e14364 (2021) doi:10.1111/ijcp.14364.

39. Wang, Z. et al. Parental acceptability of COVID-19 vaccination for children under the age of 18 years among Chinese doctors and nurses: a cross-sectional online survey. Human Vaccines \& Immunotherapeutics 0, 1-11 (2021).

40. Hageman Joseph R. Long COVID-19 or Post-Acute Sequelae of SARS-CoV-2 Infection in Children, Adolescents, and Young Adults. Pediatric Annals 50, e232-e233 (2021).

41. Opel, D. J., Diekema, D. S., Lee, N. R. \& Marcuse, E. K. Social Marketing as a Strategy to Increase Immunization Rates. Arch Pediatr Adolesc Med 163, 432 (2009). 
medRxiv preprint doi: https://doi.org/10.1101/2021.07.05.21260024; this version posted July $6,2021$. The copyright holder for this preprint (which was not certified by peer review) is the author/funder, who has granted medRxiv a license to display the preprint in perpetuity. It is made available under a CC-BY-NC-ND 4.0 International license .

42. Jarrett, C. et al. Strategies for addressing vaccine hesitancy - A systematic review. Vaccine 33, 4180-4190 (2015).

43. Holzmann-Littig, C. et al. COVID-19 vaccination acceptance among healthcare workers in Germany. medRxiv 2021.04.20.21255794 (2021) doi:10.1101/2021.04.20.21255794.

44. Verger, P. et al. Attitudes of healthcare workers towards COVID-19 vaccination: a survey in France and French-speaking parts of Belgium and Canada, 2020. Euro Surveill 26, (2021).

45. Federal Office of Public Health. COVID-19 Switzerland Information on the current situation, as of 21 June 2021 - Vaccine doses. https://www.covid19.admin.ch/en/epidemiologic/vacc-doses (2021). 
medRxiv preprint doi: https://doi.org/10.1101/2021.07.05.21260024; this version posted July 6 , 2021. The copyright holder for this preprint (which was not certified by peer review) is the author/funder, who has granted medRxiv a license to display the preprint in perpetuity.

It is made available under a CC-BY-NC-ND 4.0 International license .

\section{Tables and figures}

Table 1. 1a) Reasons for accepting or refusing vaccination, and 1b) reasons that might change participants' minds.

\begin{tabular}{|c|c|}
\hline $\begin{array}{l}\text { 1a. Reasons to get vaccinated (if vaccination intention=yes/rather yes) } \\
\left(\mathrm{N}=2^{\prime} 379^{\star}\right)\end{array}$ & $\mathbf{N}(\%)$ \\
\hline Desire to 'get back to normal' & $1866(78.4)$ \\
\hline Protect myself against infection & $1794(75.4)$ \\
\hline Protect the community/society & $1667(70.1)$ \\
\hline Desire to travel & $1637(68.8)$ \\
\hline Protect those close to me & $1510(63.5)$ \\
\hline Adherence to public health recommendations & $1145(48.1)$ \\
\hline Living or working with vulnerable people & $311(13.1)$ \\
\hline At risk of infection at the workplace & $280(11.8)$ \\
\hline At risk of complications due to age & $206(8.7)$ \\
\hline At risk of complications due to health state & $138(5.8)$ \\
\hline Vaccine recommended by healthcare professional & $107(4.5)$ \\
\hline At risk for other reasons & $72(3)$ \\
\hline Employer required vaccination & $40(1.7)$ \\
\hline $\begin{array}{l}\text { Reasons for refusing vaccination (if vaccination intention=No/rather no) } \\
\text { (N=562) }\end{array}$ & $\mathrm{N}(\%)$ \\
\hline Prefer waiting & $303(53.9)$ \\
\hline Waiting for additional information & $162(53.5)$ \\
\hline Give priority to more vulnerable people & $73(24.1)$ \\
\hline Waiting for more people to get vaccinated & $47(15.5)$ \\
\hline Waiting for my serological test result & $13(4.3)$ \\
\hline Not afraid of getting infected & $155(27.6)$ \\
\hline Not at risk of complications & $88(56.8)$ \\
\hline I protect myself & $25(16.1)$ \\
\hline I have antibodies against SARS-CoV-2 & $20(12.9)$ \\
\hline COVID-19 is a trivial disease & $13(8.4)$ \\
\hline Preference for other preventive measures & $154(27.4)$ \\
\hline Preference for natural/traditional treatments & $50(32.5)$ \\
\hline Preference for natural immunity & $46(29.9)$ \\
\hline Preference for other means of protection & $40(26)$ \\
\hline Worried or afraid to get vaccinated & $137(24.4)$ \\
\hline Afraid of long-term side-effects & $71(51.8)$ \\
\hline Vaccine developed too fast & $49(35.8)$ \\
\hline Distrust in biological mechanism of the vaccine & $14(10.2)$ \\
\hline Feel protected because previously infected by SARS-CoV-2 & $133(23.7)$ \\
\hline Believe that vaccine doesn't prevent transmission & $117(20.8)$ \\
\hline Against vaccines in general & $76(13.5)$ \\
\hline The sanitary situation is improving & $22(3.9)$ \\
\hline Can't get vaccinated for medical reasons & $6(1.1)$ \\
\hline \multicolumn{2}{|l|}{ 1c. If no/rather no, reasons that may change participants' minds $(\mathrm{N}=562)$} \\
\hline More reliable information on vaccine's efficacy & $289(51.4)$ \\
\hline Scientific results showing low risk of side effects & $284(50.5)$ \\
\hline Mandatory vaccination for certain situations (e.g. travel) & $188(33.5)$ \\
\hline Deterioration of the sanitary situation & $69(12.3)$ \\
\hline Better communication by authorities & $54(9.6)$ \\
\hline Many people in Switzerland getting vaccinated & $24(4.3)$ \\
\hline Reassuring information in the media or social media & $21(3.7)$ \\
\hline Friends or relatives getting vaccinated & $13(2.3)$ \\
\hline Will not change mind & $69(12.3)$ \\
\hline
\end{tabular}

*Does not include participants who were already vaccinated or who had an appointment to get vaccinated. 
medRxiv preprint doi: https://doi.org/10.1101/2021.07.05.21260024; this version posted July $6,2021$. The copyright holder for this preprint (which was not certified by peer review) is the author/funder, who has granted medRxiv a license to display the preprint in perpetuity.

It is made available under a CC-BY-NC-ND 4.0 International license.

Table 2. Change in intention to get vaccinated against COVID-19 in the past three months.

\begin{tabular}{lllll}
\hline Change in intention to get vaccinated & $\begin{array}{l}\text { Overall } \\
\left(\mathbf{N}=4^{\prime} 067\right) \\
\mathbf{n}(\%)\end{array}$ & $\begin{array}{l}\text { Vaccinated or } \\
\text { intend to get } \\
\text { vaccinated } \\
\mathbf{n}(\%)\end{array}$ & $\begin{array}{l}\text { No intention to } \\
\text { get vaccinated } \\
\mathbf{n}(\%)\end{array}$ & $\begin{array}{l}\text { Don't know } \\
\mathbf{n}(\%)\end{array}$ \\
\hline No & $3176(78.1)$ & $2369(76.9)$ & $491(87.4)$ & $316(74.3)$ \\
More in favor of vaccination & $805(19.8)$ & $685(22.2)$ & $33(5.9)$ & $87(20.5)$ \\
Less in favor of vaccination & $86(2.1)$ & $26(0.8)$ & $38(6.8)$ & $22(5.2)$ \\
\hline
\end{tabular}

Table 3. Reasons for change in vaccination intention in the past three months.

\begin{tabular}{lll}
\hline Reasons for change in intention & $\begin{array}{l}\text { More in favor of vaccination } \\
(\mathbf{N}=805) \\
\mathbf{n}(\%)\end{array}$ & $\begin{array}{l}\text { Less in favor of vaccination } \\
(\mathbf{N}=86) \\
\mathbf{n}(\%)\end{array}$ \\
\hline $\begin{array}{l}\text { Change in the sanitary situation } \\
\text { Information shared by public health }\end{array}$ & $490(60.9)$ & $29(33.7)$ \\
$\begin{array}{l}\text { authorities } \\
\text { New measures in place (e.g. regarding } \\
\text { travel) }\end{array}$ & $395(49.1)$ & $36(41.9)$ \\
Scientific developments & $344(42.7)$ & $18(20.9)$ \\
Information in the media & $313(38.9)$ & $13(15.1)$ \\
Advice from relatives or friends & $190(23.6)$ & $44(51.2)$ \\
Arrival of a new vaccine & $186(23.1)$ & $12(14)$ \\
Information in social media & $112(13.9)$ & $12(14)$ \\
\hline
\end{tabular}


medRxiv preprint doi: https://doi.org/10.1101/2021.07.05.21260024; this version posted July 6 , 2021. The copyright holder for this preprint (which was not certified by peer review) is the author/funder, who has granted medRxiv a license to display the preprint in perpetuity.

It is made available under a CC-BY-NC-ND 4.0 International license .

Table 4. Association of socio-demographic and health-related factors with vaccination intention

\begin{tabular}{|c|c|c|c|c|c|}
\hline \multirow[t]{2}{*}{$\begin{array}{l}\text { Socio-demographic } \\
\text { characteristics }\end{array}$} & \multicolumn{2}{|c|}{$\begin{array}{l}\text { Intention to get } \\
\text { vaccinated* }\end{array}$} & \multirow[t]{2}{*}{$\mathrm{p}$-value } & \multirow[t]{2}{*}{$\begin{array}{l}\text { Crude OR }{ }^{* *} \\
(95 \% \mathrm{Cl})\end{array}$} & \multirow[t]{2}{*}{$\begin{array}{l}\text { Adjusted OR }{ }^{* \star \dagger} \\
(95 \% \mathrm{Cl})\end{array}$} \\
\hline & $\begin{array}{l}\text { Yes/rather } \\
\text { yes/ already } \\
\text { vaccinated } \\
\left(\mathrm{N}=3^{\prime} 080\right) \\
\mathrm{n}(\%)\end{array}$ & $\begin{array}{l}\text { No/ rather } \\
\text { no } \\
(\mathrm{N}=562) \\
\mathrm{n}(\%)\end{array}$ & & & \\
\hline Sex $^{1}$ & & & $<0.001$ & & \\
\hline Female & $1631(53)$ & $357(63.5)$ & & Ref & Ref \\
\hline Male & $1440(46.8)$ & $205(36.5)$ & & $1.54(1.28-1.85)$ & $1.37(1.12-1.67)$ \\
\hline Intersex & $9(0.3)$ & $0(0)$ & & - & - \\
\hline Age category & & & $<0.001$ & & \\
\hline $18-34$ & $285(9.3)$ & $93(16.5)$ & & Ref & Ref \\
\hline $35-49$ & $803(26.1)$ & $217(38.6)$ & & $1.21(0.92-1.60)$ & $1.13(0.83-1.54)$ \\
\hline $50-64$ & $1081(35.1)$ & $194(34.5)$ & & $1.82(1.38-2.41)$ & $1.86(1.36-2.55)$ \\
\hline$\geq 65$ & $911(29.6)$ & $58(10.3)$ & & $5.15(3.63-7.37)$ & $5.55(3.79-8.19)$ \\
\hline Education & & & $<0.001$ & & \\
\hline Tertiary & $2093(68)$ & $315(56)$ & & Ref & Ref \\
\hline Secondary & $387(12.6)$ & $89(15.8)$ & & $0.65(0.51-0.85)$ & $0.67(0.51-0.89)$ \\
\hline Apprenticeship & 485 (15.7) & $135(24)$ & & $0.54(0.43-0.68)$ & $0.47(0.37-0.61)$ \\
\hline Compulsory/none & $109(3.5)$ & $22(3.9)$ & & $0.75(0.47-1.23)$ & $0.83(0.50-1.44)$ \\
\hline Household income ${ }^{2}$ & & & $<0.001$ & & \\
\hline Low & $347(11.3)$ & $89(15.8)$ & & Ref & Ref \\
\hline Middle & $1578(51.2)$ & $286(50.9)$ & & $1.41(1.08-1.83)$ & $1.23(0.93-1.61)$ \\
\hline High & 495 (16.1) & $46(8.2)$ & & $2.75(1.89-4.06)$ & $2.56(1.73-3.83)$ \\
\hline $\begin{array}{l}\text { Don't know/don't wish to } \\
\text { answer }\end{array}$ & $569(18.5)$ & 107 (19) & & - & - \\
\hline NA & $91(3)$ & $34(6)$ & & - & - \\
\hline Chronic disease & & & $<0.001$ & & \\
\hline Yes & $897(29.1)$ & $96(17.1)$ & & Ref & Ref \\
\hline No & 2183 (70.9) & $466(82.9)$ & & $0.50(0.40-0.63)$ & $0.60(0.47-0.77)$ \\
\hline Residential area & & & $<0.001$ & & \\
\hline Rural & $483(15.7)$ & $132(23.5)$ & & Ref & Ref \\
\hline Semi-urban & $1088(35.3)$ & $188(33.5)$ & & $1.59(1.24-2.03)$ & $1.59(1.22-2.07)$ \\
\hline Urban & $1508(49)$ & $242(43.1)$ & & $1.70(1.34-2.15)$ & $1.95(1.51-2.51)$ \\
\hline Employment status & & & $<0.001$ & & \\
\hline Employee & $1554(50.5)$ & $352(62.6)$ & & Ref & Ref \\
\hline Retired & $935(30.4)$ & $62(11)$ & & $3.42(2.60-4.57)$ & $1.68(1.00-2.89)$ \\
\hline Student & $120(3.9)$ & $25(4.4)$ & & $1.08(0.70-1.73)$ & 2.16 (1.19-4.09) \\
\hline Independent & $229(7.4)$ & $53(9.4)$ & & $0.98(0.72-1.36)$ & $0.77(0.55-1.09)$ \\
\hline $\begin{array}{l}\text { Househusband or } \\
\text { housewife }\end{array}$ & $131(4.3)$ & $29(5.2)$ & & $1.03(0.69-1.59)$ & $1.10(0.71-1.74)$ \\
\hline Unemployed & $81(2.6)$ & $33(5.9)$ & & $0.55(0.36-0.85)$ & $0.68(0.43-1.09)$ \\
\hline Long-term sickleave & $29(0.9)$ & $8(1.4)$ & & $0.82(0.39-1.95)$ & $1.17(0.53-2.99)$ \\
\hline Living conditions & & & $<0.001$ & & \\
\hline Alone & $460(14.9)$ & $79(14.1)$ & & Ref & Ref \\
\hline Single parent with children & $145(4.7)$ & $52(9.3)$ & & $0.48(0.32-0.72)$ & $0.69(0.45-1.05)$ \\
\hline With partner & $1051(34.1)$ & $122(21.7)$ & & $1.48(1.09-2.00)$ & $1.36(0.99-1.86)$ \\
\hline With partner and children & 1213 (39.4) & $252(44.8)$ & & $0.83(0.62-1.08)$ & $1.29(0.95-1.76)$ \\
\hline Shared apartment & $210(6.8)$ & $57(10.1)$ & & $0.63(0.43-0.92)$ & $2.40(1.32-4.45)$ \\
\hline Smoking status & & & 0.035 & & \\
\hline
\end{tabular}


medRxiv preprint doi: https://doi.org/10.1101/2021.07.05.21260024; this version posted July 6 , 2021. The copyright holder for this preprint (which was not certified by peer review) is the author/funder, who has granted medRxiv a license to display the preprint in perpetuity.

It is made available under a CC-BY-NC-ND 4.0 International license.

\begin{tabular}{|c|c|c|c|c|}
\hline Current smoker & $426(13.8)$ & $90(16)$ & Ref & Ref \\
\hline Former smoker & 1014 (32.9) & $155(27.6)$ & $1.39(1.04-1.84)$ & $1.04(0.77-1.41)$ \\
\hline Never smoker & 1639 (53.2) & $317(56.4)$ & $1.10(0.85-1.42)$ & $0.94(0.71-1.24)$ \\
\hline \multicolumn{3}{|l|}{ Previous SARS-CoV-2 } & & \\
\hline Negative & $2573(83.5)$ & $408(72.6)$ & Ref & Ref \\
\hline Positive & $507(16.5)$ & $154(27.4)$ & $0.52(0.43-0.65)$ & $0.61(0.49-0.76)$ \\
\hline \multicolumn{5}{|l|}{$\begin{array}{l}\text { Perceived severity of } \\
\text { COVID-194 }\end{array}$} \\
\hline Extremely severe & $158(7)$ & $4(1)$ & Ref & Ref \\
\hline Very severe & $608(27)$ & $27(6.6)$ & $0.58(0.17-1.50)$ & $0.29(0.05-0.99)$ \\
\hline Severe & $886(39.3)$ & $117(28.5)$ & $0.19(0.06-0.47)$ & $0.10(0.02-0.33)$ \\
\hline Rather severe & $570(25.3)$ & $225(54.7)$ & $0.06(0.02-0.16)$ & $0.04(0.01-0.12)$ \\
\hline Not at all severe & $33(1.5)$ & $38(9.2)$ & $0.02(0.01-0.06)$ & $0.01(0-0.04)$ \\
\hline \multicolumn{4}{|c|}{ Perceived contagiousness } & \\
\hline Extremely contagious & $296(13.1)$ & $12(2.9)$ & Ref & Ref \\
\hline Very contagious & $1273(56.5)$ & $170(41.4)$ & $0.30(0.16-0.53)$ & $0.25(0.11-0.46)$ \\
\hline Contagious & 448 (19.9) & $151(36.7)$ & $0.12(0.06-0.21)$ & $0.09(0.04-0.18)$ \\
\hline Rather contagious & $236(10.5)$ & 75 (18.2) & $0.13(0.06-0.23)$ & $0.12(0.05-0.23)$ \\
\hline Not at all contagious & $2(0.1)$ & $3(0.7)$ & $0.03(0-0.18)$ & $0.03(0-0.21)$ \\
\hline Vaccine Hesitancy & & & & \\
\hline Not hesitant & $2052(66.6)$ & $277(49.3)$ & Ref & Ref \\
\hline Hesitant & $1028(33.4)$ & $285(50.7)$ & $0.49(0.40-0.58)$ & $0.42(0.34-0.53)$ \\
\hline \multicolumn{5}{|c|}{$\begin{array}{l}\text { Abbreviations: } \mathrm{OR}=\text { odds ratio, } \mathrm{Cl}=\text { confidence interval, } \mathrm{NA}=\text { not available, Ref = reference. } \\
{ }^{*} \text { The number of participants having answered 'don't know' were excluded from the table to improve presentation; however, these numbers } \\
\text { are available in the supplemental material (table } \mathrm{S4} \text { ). } \\
\text { **Excluding participants who answered 'don't know' }\end{array}$} \\
\hline \multicolumn{5}{|c|}{$†$ Adjusted for sex, age, education and income } \\
\hline \multirow{2}{*}{\multicolumn{5}{|c|}{$\begin{array}{l}{ }^{1} \text { Intersex individuals and non-avalaible (NA) data in each category were excluded from logistic regression due to very low numbers; NAs } \\
\text { with low counts were also exluded from the table for simplicity of presentation. } \\
{ }^{2} \text { Income category was calculated based on living conditions (alone, with partner, with or without children, with other adults) and reported } \\
\text { household income. }\end{array}$}} \\
\hline & & & & \\
\hline \multicolumn{5}{|c|}{$\begin{array}{l}{ }^{3} \text { Positive COVID-19 status was defined as being either seropositive or having declared a positive PCR or antigenic test for SARS-CoV- } 2 \text { in } \\
\text { one of monthly surveys. } \\
{ }^{4} \text { Data obtained from monthly questionnaires sent to participants ( } N=2^{\prime} 971 \text { ) }\end{array}$} \\
\hline
\end{tabular}


medRxiv preprint doi: https://doi.org/10.1101/2021.07.05.21260024; this version posted July 6,2021 . The copyright holder for this preprint (which was not certified by peer review) is the author/funder, who has granted medRxiv a license to display the preprint in perpetuity.

It is made available under a CC-BY-NC-ND 4.0 International license .

A

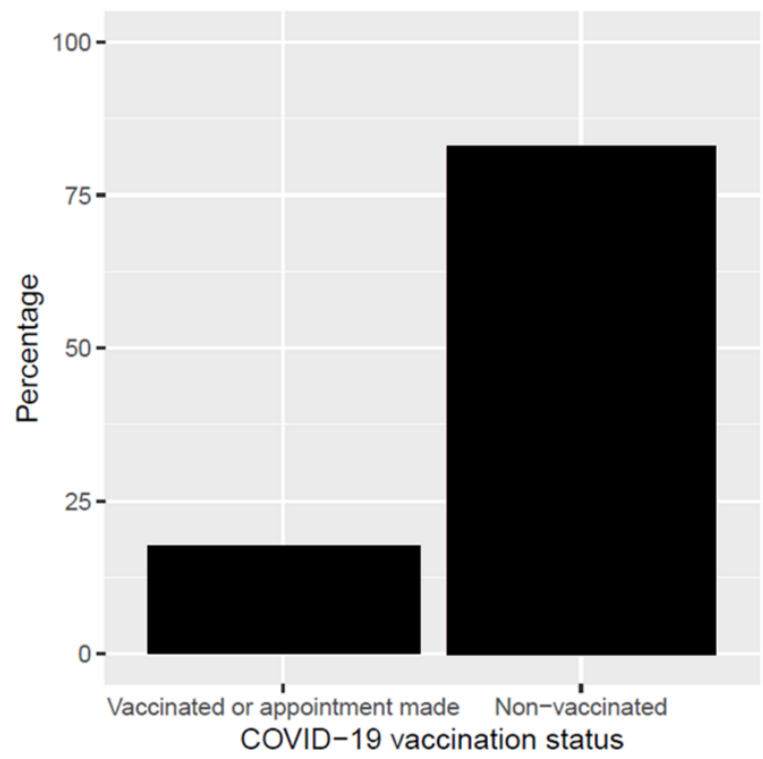

B

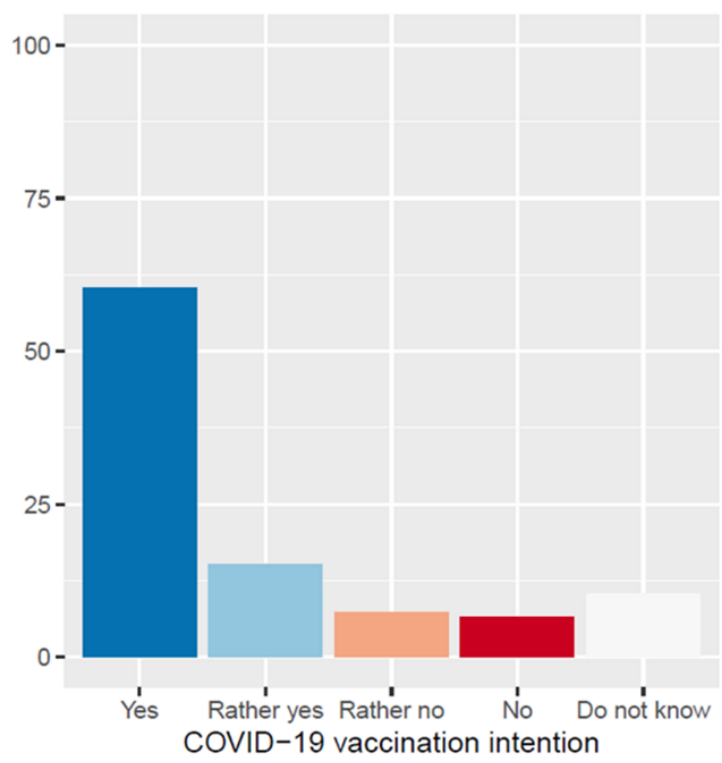

Figure 1. A. Proportion of participants vaccinated/with appointment for vaccination versus participants not vaccinated against COVID-19. B. Intention to get vaccinated against COVID-19; «Yes» combines those willing to get vaccinated and those already vaccinated or who have an appointment. 
medRxiv preprint doi: https://doi.org/10.1101/2021.07.05.21260024; this version posted July 6,2021 . The copyright holder for this preprint (which was not certified by peer review) is the author/funder, who has granted medRxiv a license to display the preprint in perpetuity.

It is made available under a CC-BY-NC-ND 4.0 International license .

A. Is the vaccine against COVID-19 is an important step to end the pandemic?
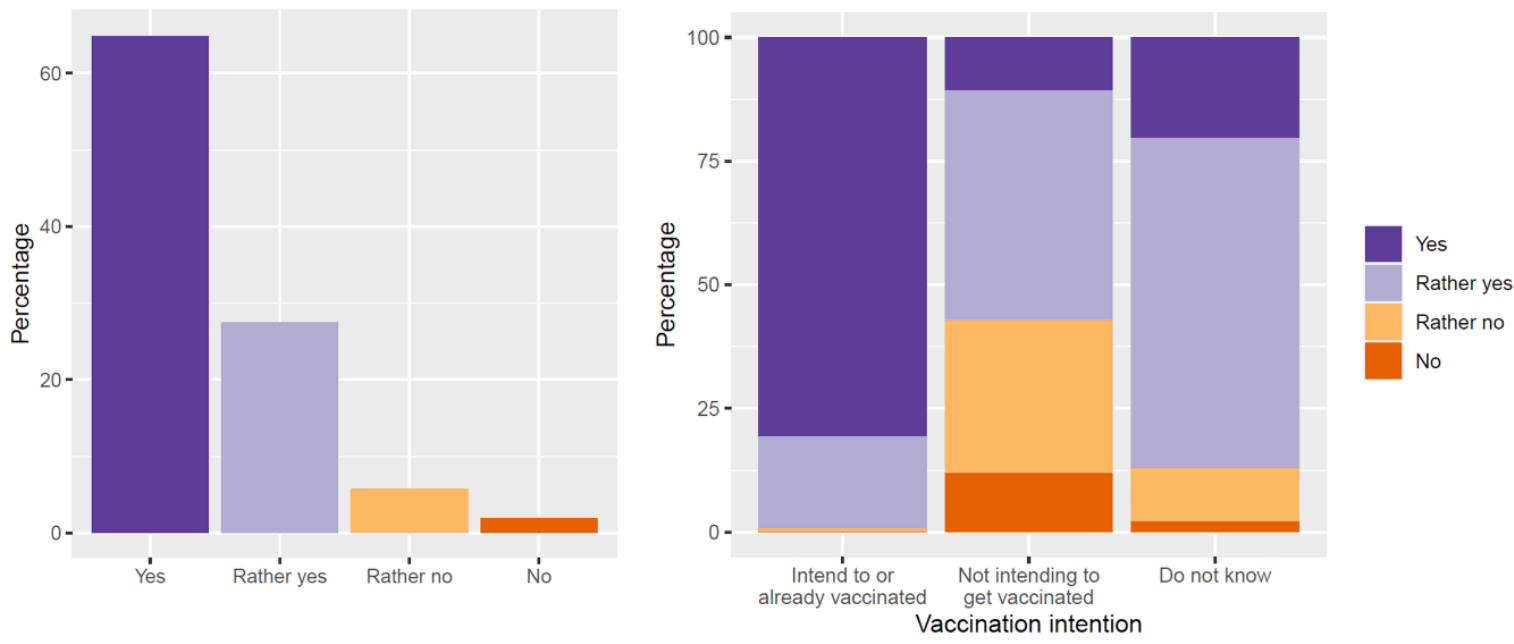

B. Should vaccinated people continue to adopt preventive measures (e.g. face masks)?
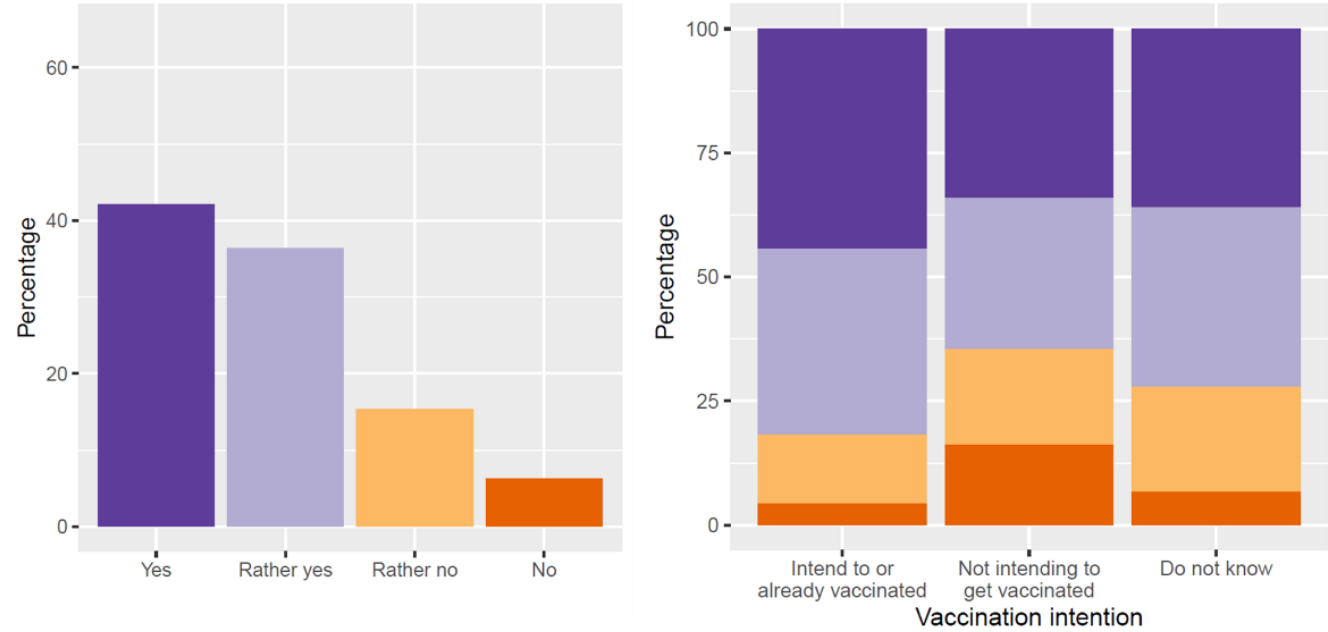

C. Would you be willing to vaccinate your children against COVID-19?
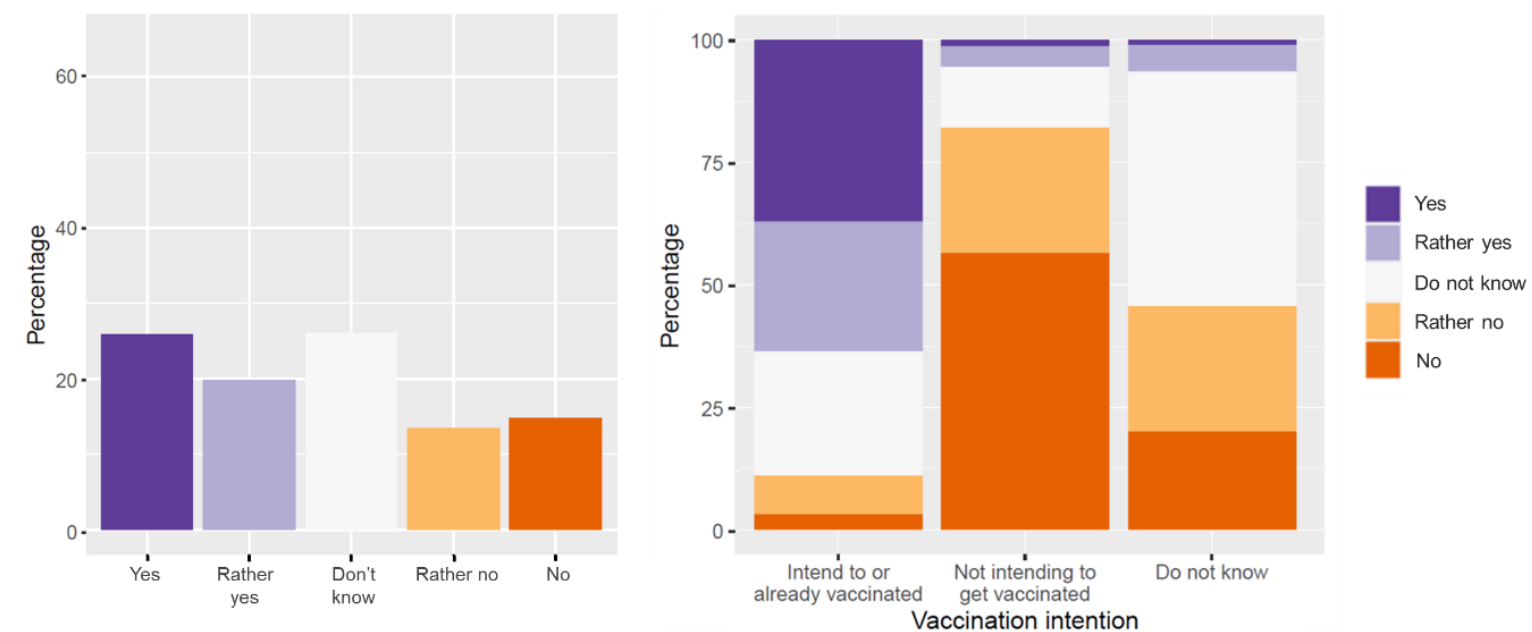

Figure 2. A. Proportion of participants agreeing that the COVID-19 vaccine is an important step to end the pandemic, in the overall sample (left) and stratified by vaccination intention (right). B. Proportion of participants agreeing that vaccinated individuals should continue to adopt preventive measures, in the overall sample (left) and stratified by vaccination intention (right). C. Proportion of participants willing to vaccinate their children, in the sample of participants with children under 18 years old (left) and stratified by vaccination intention (right). 